DOI: $10.15276 /$ ETR.02.2020.7

DOI: $10.5281 /$ zenodo.3976884

UDC: 352.071

JEL: G18, G28, H83, R58

\title{
PROMISING DIRECTIONS OF MODERN TERRITORIAL COMMUNITIES CREATION AS A CONCEPTUAL BASIS FOR REFORMING LOCAL SELF- GOVERNMENT
}

\author{
ПЕРСПЕКТИВНІ НАПРЯМИ СТВОРЕННЯ СУЧАСНИХ \\ ТЕРИТОРІАЛЬНИХ ГРОМАД ЯК КОНЦЕПТУАЛЬНІ ЗАСАДИ \\ РЕФОРМУВАННЯ МІСЦЕВОГО САМОВРЯДУВАННЯ
}

\author{
Kulinska V. Anzhela, DSc (Econ), Associate Professor, Professor \\ Odessa National Polytechnic University, Odessa, Ukraine \\ ORCID: 0000-0002-3609-3697 \\ Email: anzelakulinskaa@gmail.com
}

Received 05.01.2020

\begin{abstract}
Кулінська А.В. Перспективні напрями створення сучасних територіальних громад як концептуальні засади реформування місиевого самоврядування. Науково-методична cmamms.

3 метою формулювання перспективних напрямів створення сучасних територіальних громад як концептуальних засад реформування місцевого самоврядування, що є основою вироблення нової управлінської ідеології, спрямованої на оновлення адміністративної культури, формування готовності управлінського персоналу до прийняття рішень в умовах зростаючої свободи дій i підвищення особистої відповідальності 3 орієнтацією на служіння громадянам, в статті сформовано механізм закріплення за громадами переліку власних та делегованих повноважень щодо зміцнення позицій місцевого самоврядування в країні. Досягнення зазначеної мети слід здійснити за рахунок створення умов для сталого розвитку територіальних громад як самостійних та самодостатніх соціальних спільнот, члени яких зможуть захищати власні права й інтереси шляхом участі у вирішенні питань місцевого значення за рахунок організаційної та фінансової самостійності територіальних громад, що стане імпульсом для удосконалення відповідної державної політики, а значить, для підвищення добробуту народу України.

Ключові слова: адміністративно-територіальний устрій, держава, концепція, місцеве самоврядування, реформування, суспільство, територіальні громади
\end{abstract}

Kulinska A.V. Promising directions for the creation of modern territorial communities as a conceptual basis for reforming local self-government. Scientific and methodical article.

In order to formulate promising directions for the creation of modern territorial communities as a conceptual basis for reforming local self-government, which is the basis for developing a new managerial ideology aimed at updating the administrative culture, creating the willingness of management personnel to make decisions in the context of growing freedom of action and increasing personal responsibility with a focus on service citizens, the article has formed a mechanism for securing to communities the list of their own and delegates authority to strengthen the position of local government in the country. Achieving this goal should be achieved by creating conditions for the sustainable development of territorial communities as independent and self-sufficient social communities, whose members will be able to defend their rights and interests by participating in resolving issues of local importance through the organizational and financial independence of territorial communities, which will be an impetus for improving the relevant public policy, which means to improve the welfare of the people of Ukraine.

Keywords: administrative-territorial structure, state, concept, local self-government, reform, society, territorial communities

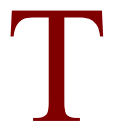

he initiated reform of local self-government is a long-awaited response to the demand of society, which needs to develop a new management ideology aimed at renewing the administrative culture, preparing management staff for decision-making under conditions of growing freedom of action and increasing personal responsibility, with a view to serving citizens. Undoubtedly, reforming the local self-government will not succeed without improving the state's existing administrative and territorial structure, in particular, the promising areas formulation for modern territorial communities creation. It should be noted that the regulation of the Cabinet of Ministers of Ukraine of 1 April 2014 № 333-r the Concept of reforming local self-government and territorial organization of power in Ukraine was approved.

The purpose of the Concept was to determine the directions, mechanisms and deadlines for forming the effective local self-government and territorial organization of government to create and maintain a full living environment for citizens, provide high quality and affordable public services, establish institutions of direct democracy, meet the citizens' interests in all spheres of life, interests coordination of the state and territorial communities. However, this goal must be achieved primarily by creating conditions for the territorial communities sustainable development as autonomous and self-sufficient social communities, whose members will be able to protect their rights and interests by participating in matters of local importance at the expense of the organizational or financial autonomy of territorial communities and local self-government bodies.

\section{Analysis of recent researches and publications}

Many well-known specialists in state and regional administration have studied the peculiarities of promising directions of modern territorial communities creation as conceptual basis for reforming local self-government in Ukraine, in 
particular, P.V. Vorona [2], R.M. Pliushch [5], M.P. Ishchenko and B.M. Huk [9] emphasize the optimal distribution of legal powers between the local self-government bodies and the executive bodies at different levels of administrative and territorial organization on the principles of subsidiarity and decentralization and taking into account human, financial, infrastructural potential and resources of the local self-government bodies at different levels.

Thus, V.B. Hroisman [3], V.S. Kuibida [8] and A.F. Tkachuk [10] note that by transforming legal powers in the state's structure, transferring authority to the local communities, the Ukrainian state receives more benefits. Structural changes are not a loss of legal powers, they make it possible to optimally attract the resources used by local authorities, which does not only lose its central importance, but on the contrary, receives a model of sustainable economic growth.

Providing the local self-government bodies with their own legal powers, within which they can act independently and be responsible for their activity, while they may be given certain legal powers of executive bodies, i.e. delegated legal powers, in the exercise of which they are controlled by the relevant executive bodies, is relevant in researches of such scientists, as O. Boryslavska, I. Zaverukha, E. Zakharchenko [1], Ya. Kotenko [4]. In addition, a significant contribution to the formulation of promising directions for the establishment of modern territorial communities as the conceptual basis for the reforming of local self-government in Ukraine was made by Ukrainian researchers, in particular V.V. Kravchenko, M.O. Baimuratov, O.V. Batanov [6] and V.M. Vakulenko, M.K. Orlatyi [7].

However, despite the large number of researches devoted to this topic, the problems of effective and rational management of communally owned property by territorial communities of villages, towns, cities directly or through local self-government bodies, programmes approval of socio-economic and cultural development and control over their implementation, budgets approval of relevant administrative and territorial units and control over their implementation, establishment of local taxes and fees in accordance with the law, ensuring local referendums and their results implementation, resolving other issues of local importance referred by law to their competence have not been sufficiently studied and need further indepth scientific analysis, which will be an impetus to improve the relevant public policy, and thus to improve the welfare of Ukrainian people.

\section{Unsolved aspects of the problem}

According to the results of the carried out studies, it has been determined that due to the significant fragmentation of territorial communities in the country, local self-government bodies of such communities are practically unable to exercise the powers granted to them by law. In addition, as it is claimed by V.V. Kravchenko, M.O. Baimuratov, O.V. Batanov [6] that the improvement requires a system of territorial organization of authority in order to improve the management of public development in the territory concerned.

Preservation of the disproportion of the administrative and territorial system as the basis of irrational territorial organization of authority (lack of an integral territory of the administrative and territorial unit of the basic level, the presence of the territorial community of the village, town, city in another territorial community or in another administrative and territorial unit) leads to conflict between the local self-government bodies, as well as between the local self-government bodies and the local executive bodies. In this regard, territorial communities expect from the Concept of reforming local self-government and territorial organization of power in Ukraine to solve the following issues [4, 8, 10]:

— providing a legal basis for the voluntary association of territorial communities, in which competent local self-government bodies are formed, capable of exercising only their own and delegated powers;

- compliance with the subsidiarity principle, which provides for transferring the functions from the local executive bodies and the territorial bodies of central executive bodies to the local selfgovernment bodies that have the closest contact with citizens;

- preventing the duplication of legal powers, functions and tasks of the local self- government bodies at different levels;

- ensuring openness and accountability to the territorial communities' population of the local self-government bodies activities and their officials;

- creating the sufficient material, financial or organizational conditions to ensure the tasks implementation of local self-government bodies;

- reforming public authorities at the local and regional levels on the principle of optimal provision of administrative and social services to the population, which reduces disparities in citizens' access to these services or their quality;

- developing mechanisms to monitor the quality of public and other legally defined services provided to the population;

- maximum involvement of territorial communities residents in management decisions, promoting the further development of modern forms of direct democratic participation on the ground.

The aim of the article is to formulate the prospects for the establishment of modern territorial communities as a conceptual basis for reforming the local self-government, which will form the basis for the developing a new managerial ideology aimed at the renewal of the administrative culture, preparing management personnel for decision-making under conditions of growing freedom of action and increased personal responsibility, with a view to serving citizens. 


\section{The main part}

As it is known, the legal powers distribution of the territorial community and its bodies defined in the Constitution of Ukraine is carried out by the Law of Ukraine "On Local Self-Government in Ukraine", which divides these rights and responsibilities between the subjects of their implementation - this is the basic level (councils, their executive bodies, village, town, city mayor) and regional level (powers of district and regional councils). A separate group consists of delegated legal powers of district and regional councils to the relevant local state administrations [2].

As for the legal powers of the representative local self-government bodies, as it is stated by M.P. Ishchenko and B.M. Huk [9], according to the mentioned Law, there are two types of powers: general and exclusive rights and obligations. General competence is defined by the Art. 25 of the Law of Ukraine "On Local Self-Government in Ukraine", according to which village, town and city councils are authorized to consider and resolve issues referred by the Constitution of Ukraine, this and other laws to their jurisdiction. Along with the general competence, the Art. 26 of the Law of Ukraine "On Local SelfGovernment in Ukraine" establishes issues that are resolved by the basic level councils in plenary sessions, which is the main organizational and legal form of councils. In our opinion, according to their content, the exclusive legal powers of these councils, based on the jurisdiction subjects, can be divided into eight groups [3].

1. Legal powers related to the implementation by the population of expression forms of will and the status determination of the population's selforganization bodies and voluntary associations of self-government bodies: decision-making on holding a local referendum; making decisions in accordance with the legislation on the organization of carrying out referendums and elections of public authorities, local self-government and village, town, city mayor; decision-making on the allocation of separate legal powers to the population's self-organization bodies by the local self-government bodies, as well as on the transfer of funds, logistics and other resources necessary for implementation; making decisions on uniting in associations or joining associations, other forms of voluntary associations of the local selfgovernment bodies and on leaving them, etc.

2. Legal powers arising from the control function of the council: hearing the report of the village, town, city mayor on the executive bodies' activities of the council; decision-making on distrust of the village, town, city mayor; hearing of deputies' reports about working in the council - execution by them of the council instructions; consideration of deputies' inquiries, decision-making on inquiries; making decisions on early legal powers termination of a deputy of the council in the manner prescribed by law; acts cancellation of executive bodies of the council that do not comply with the Constitution or laws of Ukraine, other acts of legislation, decisions of the relevant council adopted within its powers; decision-making on early legal powers termination of the village, rural settlement, city mayor in the cases provided by this Law, etc.

3. Legal powers related to the work organization of the council and the bodies formed by it: determination in accordance with the law of the council quantitative composition; council regulations approval; formation and liquidation of permanent and other council commissions, approval and change of their composition, chairmen's election of commissions; formation of the council executive committee, determination of its number, the personnel approval; election on the proposal of the village, town, city mayor to the position and dismissal of the council secretary; approval on the proposal of the village, town, city mayor the council executive bodies structure, the total number of council staff and its executive bodies, their maintenance costs; approval of the council work plan and hearing the report on its implementation; decision-making on early legal powers termination of bodies of the population's selforganization in cases provided by law, etc.

4. Legal powers in the field of programming, planning and budgetary and financial sphere: programmes authorization of socio-economic and cultural development of administrative and territorial units, target programmes on other issues of local selfgovernment; the local budget approval, modifications introduction to it; approval of the report on the relevant budget implementation; establishment of local taxes and fees in accordance with the Tax Code of Ukraine; trust funds formation, regulations approval on these funds; decision-making on local loan; making decisions on granting benefits in accordance with current legislation on local taxes and fees, as well as land tax; establishment for enterprises, institutions and organizations belonging to the communal ownership of the respective territorial communities, the size of the profit share to be credited to the local budget, etc.

5. Legal powers in the field of communal ownership management: decisions adoption on expropriation in accordance with the law of communal ownership; approval of local privatization programmes, as well as of the list of communal ownership entities that cannot be privatized; resolving issues of privatized property acquisition in accordance with the procedure established by law, inclusion of property alienated in the process of privatization in the communal ownership entities, the sales and purchasing agreement of which has been terminated or declared invalid, granting concession of communal ownership entities, on creation, liquidation, reorganization and re-profiling of enterprises, institutions and organizations of communal ownership of the territorial community; reorganization or liquidation of educational institutions of communal ownership is carried out by the local council's decision; on approval of the procedure for the supervisory board formation, the procedure for appointing the supervisory board members a communal unitary enterprise; decisions adoption on the transfer to other bodies of certain legal powers for 
the property management belonging to the communal ownership of the relevant territorial community, determining the limits of these legal powers and their fullfilment conditions; decisions, in accordance with the legislation, the issues of joint ventures establishment by enterprises, including with foreign investments, etc.

6. Legal powers in the field of nature conservation, land use, other natural resources: decision in accordance with the law on the land relations regulation; approval of land tax rates in accordance with the Tax Code of Ukraine; decision in accordance with the law on granting a permit for special using the natural resources of local importance, as well as on the revocation of such a permit; decision adoption on the organization of territories and the nature reserve fund entities of local significance and other territories subject to special protection; making suggestions to the relevant state bodies on the declaration of natural and other objects of ecological, historical, cultural or scientific value, monuments of nature, history or culture, which are protected by law, etc.

7. Legal powers in the field of settlements improvement and development: establishment in accordance with the law of rules on improvement of the settlement territory, ensuring its cleanliness and order, trade in markets, silence observance in public places, for violation of which administrative liability is provided; decisions adoption, within the limits set by law, on matters relating to the management of natural disasters, epidemics and epizootics, the violation of which is an administrative liability; territories identification where potentially dangerous activities may be carried out in the presence of civilians with the participation of the Armed Forces of Ukraine personnel, other military formations and law enforcement agencies with the use of weapons or military equipment; decisions adoption related to the creation of special free and other zones, changes in these zones status, making proposals to the relevant authorities on these issues, etc.

8. Legal powers in the field of the population's social protection, ensuring law and order, protection of rights, freedoms and legitimate interests of a man and citizen: creation in accordance with the law at the expense of the local budget institutions for free primary legal aid, heads' appointment and dismissal for these institutions, involvement in the manner prescribed by law of individuals or legal entities of private law to provide free primary legal aid; hearing information from prosecutors and heads of the National Police on the condition of justice, the fight against crime, public order and the activities results in the territory; decisions adoption on issues of administrative and territorial organization within the limits and in the manner prescribed by this and other laws, etc.

At the same time, according to O. Boryslavska, I. Zaverukha and E. Zakharchenko [1], in the conditions of reforming local self-government and territorial organization of authority there are changes in the legal powers of various public administration bodies and local self-government bodies. At this stage of decentralization, it is necessary to expand the communities legal powers in land issues. Amalgamated territorial communities have proven their effectiveness and ability to solve extremely complex issues, to be responsible for their decisions. Therefore, it is necessary to adopt a law as soon as possible, which allows joint territorial communities to influence all lands on their territory, including outside settlements.

In this regard, the Ministry of Regional Development, Construction and Housing of Ukraine has developed a draft Law of Ukraine "On Amendments to Certain Legislative Acts of Ukraine on Land Management within the Territory of United Territorial Communities" for transfer to village, town, city councils of the united territorial communities of authority to dispose of state-owned lands within the territory of the respective territorial communities. The draft Law amends the Land Code of Ukraine, the laws of Ukraine "On Local Self-Government in Ukraine" and "On Land Lease", which provide for the transfer of village, town, city councils of united territorial communities powers to [5]:

- disposal of state property lands, transfer of state property land patches to the citizens' ownership and legal entities, land patches provision for use from state property lands, within the limits specified by the Code;

- changes in the purpose of privately owned land patches in relation to land patches located within the settlement, as well as within the territory of the joint territorial communities;

- sale to citizens and legal units of state property land patches (except for land patches on which privatization objects are located) and communal property for the needs specified by this Code;

- condemnation of land and other needs of land patches from state and communal property, which were provided for permanent use, if the local selfgovernment body disposes of these plots. The draft law also defines the list of state property lands that cannot be transferred to communal ownership, and defines the term "territorial community territory". Amendments to the Law of Ukraine "On Land Lease" provide that landlords of land patches of state and communal ownership are the Verkhovna Rada of the Autonomous Republic of Crimea, the executive authorities and the local self-government bodies, which transfer land patches of state or communal ownership for use in accordance with the powers specified in the Art. 122 of the Code.

As for the delegated legal powers, they, as Ya. Kotenko [4] emphasizes, deserve a separate theoretical consideration. The transfer of more legal powers to the local self-government bodies is accompanied by a simultaneous increase in the bodies responsibility. Strengthening the position of local selfgovernment in the country will increase the responsibility to citizens to ensure their proper living standard. In recent years, there have been changes in the delegated legal powers of the executive bodies of 
village, town, city councils, namely: participation in the state regulatory policy implementation within and in the manner prescribed by the Law of Ukraine "On Principles of State Regulatory Policy"; organizational support of the administrative services provision by executive bodies through the centres of the administrative services provision.

It is determined that the Concept envisages assigning the largest list of powers to communities (villages, towns, cities). The local self-government bodies receive the necessary personnel, financial resources and infrastructure capacity for the proper implementation of their legal powers. Let's take a closer look at the powers of the amalgamated territorial communities (Fig. 1). It should be noted that the communities united in accordance with the law and the long-term plan receive the full range of legal powers that currently have cities of regional significance. In particular, the list of expenditure legal powers of the amalgamated territorial communities is defined in the Art. 89 and 91 of the Budget Code of Ukraine (the Art. 89 - expenditures made from the cities budgets of the Republican Autonomous Republic of Crimea and regional significance, district budgets, budgets of amalgamated territorial communities, created in accordance with the law and long-term plan of community formation; the Art. 91 - local budget expenditures that can be made from all local budgets) [6].

In general, legal powers are delegated by the state to the local self-government bodies operating at the level of administrative and territorial organization at which it is possible and appropriate to exercise them given the human, financial, infrastructural potential and resources required to implement legal powers at this level. The Concept states that for the optimal distribution of legal powers between the local selfgovernment bodies and the executive bodies at different levels of administrative and territorial structure it is necessary to ensure [8]: improving the system of public involvement in the management decisions development and control over their implementation; determination of a sufficient tax base that will allow the local self-government bodies to exercise their own legal powers, taking into account the objective criteria for financing of delegated legal powers by the state; formation at each administrative and territorial level of the representative local selfgovernment bodies with their own executive bodies; effective state control over the observance by local self-government bodies of the requirements of the Constitution and laws of Ukraine.

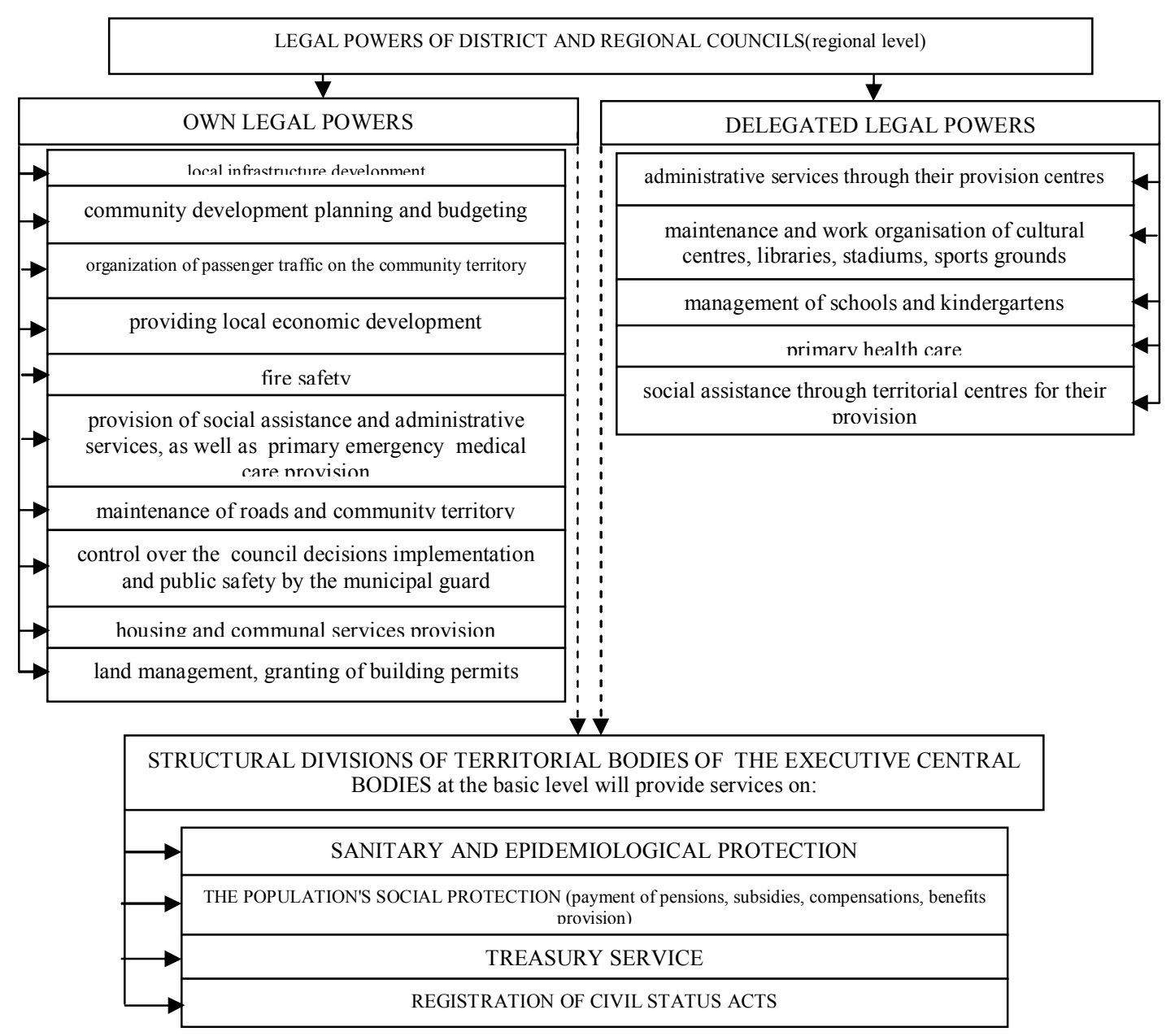

Figure 1. Mechanism for Assigning to Communities a List of Their Own and Delegated Legal Powers to Strengthen the Local Self-Government Position in Ukraine Source: author's own development 
Therefore, the creation of appropriate material, financial, organizational conditions and staffing to ensure the implementation of local self-government bodies of their own and delegated legal powers should be carried out in accordance with the following principles $[7,10]$ :

- availability of the resources necessary for the exercise of the statutory powers of local selfgovernment bodies;

- securing for local budgets part of the funds received from the payment of income tax of newly created legal entities, within five years from the date of investment in the legal unit;

- granting the local self-government bodies with access to attract credit resources for investment development by simplifying the procedures for agreeing on borrowings and local guarantees and balancing them with the methods of state control aimed at preventing the bankruptcy of communal ownership;

- granting the territorial communities the right to dispose of land resources within their territory, pool their property and resources in the framework of territorial communities cooperation to implement joint programmes and more effective provision of public services to the population of adjacent territorial communities;

- introducing the effective mechanisms of public participation in the important management decisions development by local self-government bodies, in particular on determining the strategy of the territorial community development, approval of the territorial communities statutes, urban planning documentation projects;

- granting the citizens' general meeting at their place of residence, in accordance with the law and in accordance with the territorial community statute, the right to initiate extraordinary reporting by officials of local self-government to the territorial community; as well as establishing the obligation for local self-government bodies and their officials to justify their own decisions on taking into account or not taking into account the decisions of the society's general assembly;

- improving the procedure for forming bodies of the population's self-organization, defining a clear procedure for granting them part of the legal powers of local self-governments bodies, as well as providing funds for the exercise of the defined legal powers, spending such funds, reporting on their use;

— introducing a mechanism for the local public administrations to exercise state control over the compliance of local self-government bodies decisions with the Constitution and laws of Ukraine and the public services quality provided to the population;

- depriving local councils of the right to express distrust to the heads of the respective local public administrations.

Thus, decentralization is understood as a redistribution process of legal powers and competences between the central and local levels of public authority with a shift of emphasis to the local level in terms of the implementation of pre-defined and guaranteed functions by the state. Considering the decentralization problems, in particular, promising areas of modern territorial communities as a conceptual basis for local self-government reform, it is important to find a balance of centralization and decentralization as a need to ensure the effective operation of local and central government bodies. Among the reasons that motivate the transfer of more legal powers to local self-government bodies are the higher level of efficiency and accountability of local self-government bodies, better prospects for local development, as well as the participatory democracy introduction and human rights protection.

\section{Conclusions}

It is determined that in the conditions of reforming the local self-government and territorial organization of authority there are changes in the legal powers of various public authorities and local self-government bodies. At this stage of decentralization, it is necessary to expand the communities legal powers in land issues. Amalgamated territorial communities have proven their effectiveness and ability to solve extremely complex issues, to be responsible for their decisions. Therefore, it is necessary to adopt a law as soon as possible, which allows amalgamated territorial communities to influence the lands on their territory, including outside the settlements.

It is proved that the transfer of more legal powers to the local self-government bodies is accompanied by a simultaneous increase in the bodies responsibility. Strengthening the local self-government position in the country will increase the responsibility to citizens for ensuring a decent living standard. In recent years, there have been changes in the delegated legal powers of executive bodies of village, town, city councils, namely, participation in the state regulatory policy implementation and organizational support for the administrative services provision by executive bodies through administrative service centres.

It is noted that for the optimal distribution of legal powers between the local self-government bodies and the executive bodies at different levels of administrative and territorial organization it is necessary to ensure: improving the system of public involvement in the management decisions development and control over their implementation; a sufficient tax base determination that will allow the local self-governments bodies to exercise their powers, taking into account the objective criteria for financing delegated legal powers ; creation at each administrative and territorial level the representative bodies of local self-government with their own executive bodies; effective state control over the observance by local self-government bodies the requirements of the Constitution and laws of Ukraine.

It is established a mechanism for consolidating the list of own and delegated legal powers for communities to strengthen the position of local selfgovernment in the country. The achievment of the 
required goal is fulfilled by creating conditions for the sustainable development of territorial communities as autonomous and self-sufficient social communities, whose members will be able to defend their rights and interests by participating in issues of local importance at the expense of the organizational and financial autonomy of the territorial communities which is the impetus for the relevant public policies improvement; and, therefore, to improve the welfare of Ukraine's people.

\begin{abstract}
The aim of the article is to formulate promising directions for modern territorial communities creation as conceptual foundations for reforming the local self-government, which will become the basis for developing a new managerial ideology aimed at updating the administrative culture, forming the readiness of management personnel to make decisions in the context of increasing freedom of action and increasing responsibility to serve the citizens.

It is determined that in the conditions of reforming local self-government and territorial organization of power there are changes in the legal powers of various public authorities and local self-government bodies. At this stage of decentralization, it is necessary to expand the communities legal powers in land issues. Amalgamated territorial communities have proven their effectiveness and ability to solve extremely complex issues, to be responsible for their decisions. Therefore, it is necessary to adopt a law as soon as possible, which allows amalgamated territorial communities to influence the lands on their territory, including outside the settlements.

It is proved that the transfer of more legal powers to local self-government bodies is accompanied by a simultaneous increase in the bodies responsibility. Strengthening the local self-government position in the country will increase the responsibility to citizens for ensuring a decent living standard . In recent years, there have been changes in the delegated legal powers of executive bodies of village, town, city councils, namely, participation in the state regulatory policy implementation and organizational support for the administrative services provision by executive bodies through administrative service centres.

It is established a mechanism for consolidating the list of own and delegated legal powers for communities to strengthen the position of local self-government in the country. .This goal is achieved by creating conditions for the sustainable development of territorial communities as independent and self-sufficient social communities, whose members can protect their own rights and interests by participating in solving local issues at the expense of organizational and financial autonomy of territorial communities, which is an impetus for improvement of the respective public policy and hence to promote the welfare of Ukraine's people.
\end{abstract}

\title{
Список літератури
}

1. Бориславська О. Децентралізація публічної влади: досвід європейських країн та перспективи України / О. Бориславська, І. Заверуха, Е. Захарченко. - К.: ТОВ «Софія», 2014. - 128 с.

2. Ворона П.В. Місцеве самоврядування України в контексті розвитку представницької влади: [моногр.] / П.В. Ворона. - Полтава: ПУЕТ, 2016. - 341 с.

3. Досвід децентралізації у країнах Європи / заг. ред. В.Б. Гройсмана. - К.: Інститут законодавства Верховної Ради України, 2015. - 766 с.

4. Котенко Я. Локальна ідентичність як умова розвитку об'єднаних територіальних громад / Я. Котенко. - К.: ІКЦ «Легальний статус», 2016. - 144 с.

5. Місцеве самоврядування в умовах децентралізації влади в Україні: [моногр.] / за заг. ред. Р.М. Плюща. - К.: РІДНА МОВА, 2014. - 744 с.

6. Актуальні проблеми становлення та розвитку місцевого самоврядування в Україні: [моногр.] / за ред. В.В. Кравченка, М.О. Баймуратова, О.В. Батанова. - К.: Атака, 2017. - 864 с.

7. Загальні засади місцевого самоврядування в Україні: [підручник] / за заг. ред. В.М. Вакуленка, М.К. Орлатого. - К.: НАДУ, 2016. - 401 с.

8. Куйбіда В.С. Організаційно-правові аспекти місцевого самоврядування в Україні: [навч. посіб.] / В.С. Куйбіда. - К.: Ун-т «Україна», 2015. - 158 с.

9. Правове забезпечення державного управління і місцевого самоврядування: [навч.-метод. посіб.] / М.П. Іщенко, Б.М. Гук. - Черкаси: Вид-во ЧНУ ім. Б. Хмельницького, 2017. - 228 с.

10. Ткачук А.Ф. Місцеве самоврядування та децентралізація. Законодавство / А.Ф. Ткачук. - К.: ІКЦ «Легальний статус», 2018. - 180 с.

11. Burkinsky, B., Goriachyk, V., Murzanovskiy, G. (2018). Адміністративно-територіальна реформа України: системне уявлення. Economic innovations, $20(3$ (68)), 8-19. 


\section{References:}

1. Boryslavska, O. (2014). Decentralization of public power: experience of European countries and prospects of Ukraine. Kyiv: Sofiya [in Ukrainian].

2. Vorona, P.V. (2016). Local self-government of Ukraine in the context of development of representative power. Poltava: PUET [in Ukrainian].

3. Grojsman, V.B. (2015). Experience of decentralization in European countries. Kyiv: Instytut zakonodavstva Verxovnoyi Rady Ukrayiny [in Ukrainian].

4. Kotenko, Ya. (2016). Local identity as a condition for development of united territorial communities. Kyiv: Legalnyj status [in Ukrainian].

5. Plyushh, R.M. (2014). Local self-government in the conditions of decentralization of power in Ukraine. Kyiv: RIDNA MOVA [in Ukrainian].

6. Kravchenko, V.V., Baymuratov, M.O., \& Batanov, O.V. (2017). Actual problems of formation and development of local self-government in Ukraine. Kyiv: Ataka [in Ukrainian].

7. Vakulenko, V.M., \& Orlatyj, M.K. (2016). General principles of local self-government in Ukraine. Kyiv: NADU [in Ukrainian].

8. Kujbida, V.S. (2015). Organizational and legal aspects of local self-government in Ukraine. Kyiv: Un-t "Ukrayina" [in Ukrainian].

9. Ishhenko, M.P., \& Guk, B.M. (2017). Legal support of public administration and local self-government. Cherkasy: Vyd-vo ChNU im. B. Xmelnyczkogo [in Ukrainian].

10. Tkachuk, A.F. (2018). Local self-government and decentralization. Legislation. Kyiv: Legalnyj status [in Ukrainian].

11. Burkinsky, B., Goriachyk, V., Murzanovskiy, G. (2018). Administrative-territorial reform of Ukraine: systemic representation. Economic innovations, 20 (3 (68)), 8-19.

\section{Посилання на статтю:}

Kulinska A.V. Promising directions for the creation of modern territorial communities as a conceptual basis for reforming local self-government / A.V. Kulinska // Економіка: реалії часу. Науковий журнал. - 2020. - № 2 (48). - C. 51-58. - Режим доступу до журн.: https://economics.opu.ua/files/archive/2020/No2/51.pdf. DOI: 10.15276/ETR.02.2020.7. DOI: 10.5281/zenodo.3976884.

\section{Reference a Journal Article:}

Kulinska A.V. Promising directions for the creation of modern territorial communities as a conceptual basis for reforming local self-government / A.V. Kulinska // Economics: time realities. Scientific journal. - 2020. - № 2 (48). - C. 51-58. - Retrieved from https://economics.opu.ua/files/archive/2020/No2/51.pdf.

DOI: 10.15276/ETR.02.2020.7. DOI: 10.5281/zenodo.3976884. 